TANULMÁNYOK 2020/1. Bölcsészettudományi Kar, Újvidék

STUDIJE 2020/1. Filozofski fakultet, Novi Sad

STUDIES 2020/1. Faculty of Philosophy, Novi Sad

ETO: 94(497.13)"19"

94(73)" $19 "$

DOI: $10.19090 / \mathrm{tm} .2020 .1 .127-138$

A kézirat leadásának időpontja: 2020. március 15.

Közlésre elfogadva: 2020. május 20.

\title{
SOMOGYVÁRI Lajos
}

Pannon Egyetem, Modern Filológiai és Társadalomtudományi Kar

Tanárképző Központ

Veszprém, Magyarország

somogyvari.lajos@mftk.uni-pannon.hu

\section{TÜNTETÉS AMERIKAI OLVASATBAN: ZÁGRÁBI EGYETEM, 1951}

\section{Demonstracije $u$ američkom tumačenju: Univerzitet u Zagrebu, 1951}

\section{Demonstrations in American Interpretation: University of Zagreb, 1951}

Az USA Külügyminisztériumának jelentéseit digitalizáló Gale számos olyan forrást tett közzé tematikus gyűjtemények formájában, melyek Kelet-Közép-Európa 1945 utáni történetéhez fontos adalékokat szolgáltatnak. A hidegháború nemcsak hadászati-politikai konfrontációt és kompetíciót jelentett a két blokk között, hanem kulturális versenyt is, melyben létfontosságú volt, hogy a két szuperhatalom minél több információt szerezzen egymás intézményeiről, a sebezhető pontokról. Amerikai részről sokat megtudhatunk erről, hiszen online kutatható számos dokumentum (a szovjet fél hasonló irányú tevékenységéről ez nem mondható el) tanulmányom a II. világháború utáni új jugoszláv rendszer első nagyobb diákmegmozdulásáról szól, mely a Zágrábi Egyetemen zajlott le 1951. október 31-én. Mindennek amerikai olvasatait mutatom be két konzuli beszámoló és egy CIA-jelentés alapján, melyek különösen fontosak, hiszen kevés kívülálló, nem szocialista nézőpontot tükröző forrás maradt fenn hasonló eseményekröl.

Kulcsszavak: diáktüntetés, az USA Külügyminisztériuma, CIA, hidegháború, Zágrábi Egyetem

\section{Bevezetö: a forrásanyag}

A Gale Company egy profitorientált vállalat, mely az USA Department of State (Külügyminisztérium) iratanyagát Archives Unbound (feloldott/szabaddá tett források) gyüjteményében tette közzé - ehhez az adatbázishoz néhány napos 
ingyenes hozzáférésem volt 2018 szeptemberében, ekkor töltöttem le a vonatkozó anyagokat. Az amerikaiak által szatellitországoknak nevezett, a szovjet blokkba tartozó államok közül nagy figyelmet fordítottak Jugoszláviára, több okból is:

- egyrészt itt szabadabban müködhettek (már az ötvenes évek elején is) a nyugati kulturális szervezetek, melyek kiszorultak máshonnan (Somogyvári 2019, az USA információs szolgálatához tartozó, Budapesten és Bukarestben bezárt könyvtárak is Belgrád és Zágráb székhelyekkel müködtek tovább az 1940-es évek végétől, lásd Konta 2016: 45);

- a szocialista térségen belüli különutas politika, a Sztálinnal való szakítás felértékelte a térséget;

- végül Jugoszlávia geopolitikai-stratégiai okokból (kijárat a Mediterráneumra) is fontos volt az USA-nak (Milošević 2007).

Az 1945 és 1963 közötti periódus külügyminisztériumi bizalmas iratai (Classified Files: Records of the Department of State) között található a Jugoszláviával (Socialism and National Unity in Yugoslavia) foglalkozó gyüjtemény. Ennek alcsoportja a belső gazdasági, ipari és társadalmi ügyek csoportja (Internal Economic, Industrial and Social Affairs), aminek pedig része az 1950-től 1954-ig, oktatás témakörében összegyüjtött forráskorpusz: ebben kapott helyet az elemzés alapjául szolgáló két jelentés. A levéltári struktúraleírás öt szintje (minisztériumi, országra, annak belső fejlődésére vonatkozó, altémára utaló és konkrét dokumentum) koncentrikus, egyre szükülö halmazokat ad ki, a legalsó fokozatba besorolt, a továbbiakban vizsgálandó két hivatalos akta a következő:

- Student Demonstration at Zagreb University on Oct. 31, 1951. 1951

- More about Professor Kušević. 1951.

Valamennyi jelentés fejléce hasonló, a legfontosabb adatok rögzítésére alkalmas, ahogyan az 1. kép is mutatja: leolvashatjuk erről a biztonsági besorolást (Classification), a feladót (From) és címzettet (To), a tárgyat (Subject), a dátumot (Date), az esetleges utalásokat (Ref.) más iratokra, tényekre, a jelentés számát (Desp. No.), a továbbítás módját (Priority), továbbá az ügymenet szokásos jelzéseit.

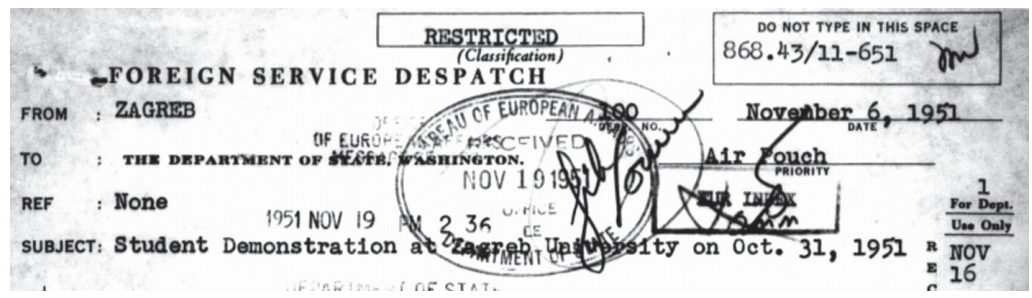

1. kép. Irat fejléce (Student Demonstration..., 1951) 
A forráshoz való hozzáférés eredeti minősítése korlátozott (restricted) volt, ez azóta áteshetett egy titkosítás alóli feloldásról szóló folyamaton (declassification), így vált olvashatóvá. A Zágrábból a washingtoni Külügyminisztériumba légicsomagként (air pouch) jutott el, nem található más iratokra való utalás (none), a pecsétekből, jelzésekből látható, hogy kevesebb mint két hét alatt az Európai Ügyekkel Foglalkozó Hivatal (Bureau of European Affairs) megkapta a benne foglaltakat. Mindkét jelentést Charles P. McVicker, az akkori zágrábi konzul írta alá, aki 1950 augusztusa óta dolgozott ezen az állomáshelyen - a belgrádi és zágrábi amerikai hivatalnokok névsorát végignézve feltünő, hogy a 32 alkalmazottból csak ketten voltak, akik a Sztálin-Tito-szakítás előtt is már itt dolgoztak, a többiek mind 1949-1950-ben érkeztek (Foreign Service List... 1951: 98-99). McVicker a későbbiekben sokat idézett Jugoszlávia-szakértővé nőtte ki magát, aki az országot sajátos kompromisszumként mutatta be az amerikai közönségnek, egyfajta korlátozott kommunizmusként, ami a nyugati liberalizmus egyes elemeit is magába olvasztotta (McVicker 1957). Paradox módon az amerikai konzul által a jelentéseiben és a könyvében is leírt 1951-es zágrábi diáktüntetés az előző mondatban ismertetett koncepciót alátámasztó, illetve ennek ellentmondó bizonyítékként is értékelhető. Egyrészt egy hasonló demonstráció elképzelhetetlen lehetett volna az 1951-es évben a keleti blokk bármely országában, ami a rendszer viszonylagos szabadságát jelezhette (McVicker majd emellett érvel); másrészt viszont ez a tény akár a lakosság fokozódó elnyomásának is a következménye lehetett, az ellenállás növekedésének jelzéseként. Mint mindig, a valóság ennél bonyolultabb, az elemzés elött azonban egy rövid kitérőt kell tenni, az ellenállás és kollaboráció jelentkezési formáiról a kommunista rendszerekben, mely több vitát kavart már a történettudományban.

\section{Elméleti háttér}

A különböző demonstrációk, spontán megmozdulások elemzése kedvelt téma a kommunista/szocialista időszakkal foglalkozó historiográfiában, hiszen egyrészt kevés ilyenről van tudomásunk (főleg az 1953 előtti időszakban), másrészt, ha fenn is maradt a hasonló tüntetések nyoma a forrásokban, az leginkább tendenciózus, a marxista nyelvhasználatnak megfelelő értelmezési keretet kapott (a nyelv valóságérzékelést átalakító szerepéről lásd Kotkin 1997, különösen a Speaking Bolshevik című fejezet: 198-237). Jelen esetben itt az ellenideológia egy (megértő, a szocialista rendszert másoknál jobban elfogadó) képviselője magyarázza meg a szituációt, a kívülálló nézőpontjából, ami mindenképpen egyedivé teszi a leírást.

A kommunista rendszerek kedvelt megközelítési módjai közé tartozik a démonológia, a bűnösök és felelősök keresése, a pártvezetők, erőszakszer- 
vek és állambiztonság képviselői, az ügynökök személyében; valamint ennek ellenpontja a mártirológia, az áldozatok felmutatása, a táborokat, börtönöket megjárt, internálást és egyéb szörnyüségeket elszenvedett emberekről, a rendszer ellenségeiről. Természetesen mindkét szemlélet alátámasztására találunk bizonyítékokat a múltból. Fontos azonban látnunk, hogy ez a fajta dichotóm látásmód (ami a kommunista ideológiára is jellemző, amire jó példa a történelem „manicheista” értelmezése a gonosz reakció és a jó haladó világ harcáról, lásd Apor 2014, 16), az elnyomó állam és az ellenálló társadalom szembenállásáról egyszerüsít, bizonyos mértékig torzítja a valóságot és felment a felelősség, az önvizsgálat alól, hiszen, aki szenvedett az elmúlt rendszerben, a „társadalom” többsége, az nem lehetett bűnös. Az újabb kutatások alapján azonban úgy tünik, hogy a rendszer egyáltalán nem volt totális, mindent kontrolláló természetü, időnként engedményekre, korrekciókra is kényszerült (legújabb összefoglaló szintézise ennek: Békés 2019); másrészt a fenntartásához is rengeteg ember helyi szinteken való közremüködésére, a fennálló uralom egyfajta hallgatólagos elfogadására is szükség volt.

A legfontosabb megjegyzés, hogy mindig szituáció-, ember- és csoportfüggő kontextusokkal találkozunk, ha hasonló egyedi eseteket vizsgálunk, ami gyakran ellentmond a hagyományos elképzeléseinknek: itt például az egyetem vezetése és a rendőrség játszik majd az előítéleteinket megcáfoló vagy legalábbis látszólag megcáfoló szerepet. A nyílt represszió és a rezisztencia két végpólusa között számos változata létezett az alkalmazkodó, a különböző szituációkat egyéni életstratégiáikban kihasználó magatartásformáknak, melyek gyakran sikerhez vezethettek lokális közösségekben - ennek ismert példái a kollektivizálással szembeni rejtett, időnként tüntetésekben kitörő paraszti ellenállás különböző formái (Lynne 1996, Farkas 2016), vagy a hivatalokkal szembeni állampolgári attitüdök, az egyéni célok elérése érdekében (Nagy 2014). Számos esetben az uralmon lévő, marxista ideológiához köthető politikai érveket, diskurzusokat használtak fel a hatalom nélküli egyének, csoportok a hivatalos szervekkel szemben, hogy céljaikat elérjék, mely az ilyen akciók interpretációját mindig többrétegűvé teszi.

\section{A tüntetés értelmezési rétegei I. Oktatási konfliktus}

Jelen esetben legalább két értelmezési síkkal rendelkezik az 1951. október 31-i, zágrábi egyetemi tüntetés - az utóéletét és a korabeli narratívákat illetően is. Első megközelítésben egy teljesen hagyományos pedagógiai konfliktusról van szó, hiszen egy egyetemi oktató túl sok hallgatót megbuktat a vizsgán, akik ezt sérelmezik, igazságtalannak érzik, és elérik a rektornál, hogy az illető 
müködését szüneteltessék. Egy ideológiailag túlterhelt, totalizáló környezetben azonban minden cselekvés egyben politikai tett is (Johnson 1996, 290), ahogyan ezt ebben az esetben szintén láthatjuk majd. Nem elégségesek ugyanis a tanár eltávolításához az esetleges szakmai érvek, hanem kellenek az ezt megtámogató politikai bizonyítékok a rendszerrel szembeni ellenséges attitüdökröl, és valójában - a jelentések alapján - ez utóbbiak lesznek a döntők. Ma már nem kideríthető természetesen a vádaskodások valóságalapja, ami lényeges, az a hatalom elvárásait sikeresen fel- és kihasználó, céljait elérő „alattvalói” logika.

Az első jelentés a tüntetés kivételességét a változó idők markáns jeleként emelte ki, a belgrádi és szarajevói egyetem hallgatói egyébként utólag gratuláló táviratokat küldtek Zágrábba (Student Demonstration... 1951, a további értékelö, leíró megjegyzések innen származnak). A megmozdulást kirobbantó ügyet lényegtelennek ítélte $\mathrm{McVicker}$, a legfontosabb szerinte az volt, hogy egyáltalán megvalósult a demonstráció: az 1945 utáni rendszerben ez volt az első ilyen esemény, ami egy évvel korábban még elképzelhetetlen lett volna. De mi történt 1951. október 31-én, a Zágrábi Egyetemen? Ezen a napon 1500 diák tüntetett a Rektori Hivatal előtt Rajko Kušević, az egyetem professzora ellen (az egyik forrásban a Műszaki Főiskola oktatója, a másikban a Technikai/Technológiai Tanszéké), az események közvetlen kiváltó oka egy két héttel azelötti incidens volt, amikor a statisztikavizsgán a teljes évfolyam (több mint 50 hallgató) megbukott. A diákok először a dékántól kértek segítséget, a professzort rendkívül szigorú, összeférhetetlen emberként jellemezve, aki a korábbi években is sok elégtelent osztott ki, és gyakran tett becsmérlő megjegyzéseket a tanszék más oktatóira. A dékán nem tett semmit, ezt követően Kušević-ellenes jelszavak jelentek meg a faliújságokon, erre viszont a kari vezető már drasztikus lépéseket helyezett kilátásba a hangadók ellen, amit aztán meg is tett, miután nem hagyott alább a diákok ellenállása.

1951. október 31-e reggelén a tanszék ajtajai zárva maradtak a hallgatók előtt, akik erre tüntetésbe kezdtek, a Rektori Hivatal felé vonulásuk közben sokan csatlakoztak hozzájuk, transzparenseik is voltak, ami jelezte, hogy elöre készülhettek erre. A tüntető hangok közé az áremelések elleni jelszavak is keveredtek, de az alapvető célkitűzés az oktatóval szembeni fellépés maradt végig. Másfél óra után feloszlott a tömeg, de nem a rektor felhívására, hanem a jelen lévő kommunista diákvezetők hatására, akiket egy miniszteri utasítás tett közvetlenül felelőssé a felvonulók viselkedéséért - a leírtak alapján tehát az ifjúsági funkcionáriusok együtt meneteltek társaikkal, ami rendkívül fontos részlet. A zágrábi amerikai konzul szerint azt jelezhette ez az újabb rendkívüli mozzanat, hogy az illetők megfeledkeztek a pártfegyelemről (vagy saját kezükbe vették annak értelmezését), lehetséges, hogy a szervezéshez is közük volt, nem csak csatlakoztak. 
A tömeg szétszéledése után a rektor fogadta a hallgatók delegációját, és kompromisszumos megoldás született: az egyetemi szenátus kivizsgálja az ügyet, a dékán visszavonja a fenyegetéseit, cserébe a diákoknak el kellett távolítaniuk a professzorellenes jelszavaikat a faliújságokról. A megállapodás sokféleképpen értékelhető: a hatalom meghátrálásaként, időnyerő akcióként, a diákok győzelmeként vagy becsapásaként (ezt a további események döntik majd el), de mindenképpen meglepő momentum, mely rácáfol elözetes feltételezéseinkre elnyomók és elnyomottak hagyományos viszonyrendszeréről, cselekvéseik dinamikájáról.

A leírás következő érdekes megjegyzése a rendőrök szerepére utal, akik az esemény során nem avatkoztak közbe, engedelmeskedve az egyetemi utasításnak, ami megtiltotta nekik a kampusz területére való belépést(!), ők pedig tiszteletben tartották az egyetemi autonómiát. Ilyen utasítást csak a rektor adhatott ki - ezek szerint nem akarták igénybe venni az erőszakszervek segítségét a probléma megoldásában, pedig egy ilyen tüntetésre logikusan ezt várnánk el reakcióként egy pártállam elnyomó hatalmának képviselőitől; a rendőrök viselkedése is érdekes, lehet, hogy jól is jött nekik a tiltás, mert nem akartak volna akcióba lépni. Az összefoglalásban McVicker arra következtetett, hogy nem bocsátják el Kuševićet (az is jelzésértékű, hogy ez a lehetőség egyáltalán szóba jöhetett) habár a vádak igazak, de egy ilyen precedensteremtő alkalmat inkább kerülne az egyetem, és statisztikatanárból amúgy is ő volt az egyetlen.

\section{A tüntetés értelmezési rétegei I. Politikai síkra terelés}

1951. november 29-én már olyan értelmü jelentést küldött McVicker, ami cáfolva az előzőt, inkább azt valószínüsítette, hogy leváltják a professzort (More about Professor Kušević 1951, a további elemzés ezen alapul). Mi változott az eltelt hetekben? Az egyetemisták olyan bizonyítékokat produkáltak, amit már nem lehetett nem tudomásul venni: Kušević például állítólag kijelentette, hogy a partizánmozgalomban vagy a kommunista pártban való részvétel még nem elégséges a matematikai tanulmányokhoz. A hallgatók között számos katona volt, aki korábban partizánként tevékenykedett és lojálisan viszonyult a párthoz, így a hasonló megjegyzéseket nagyon dühösen fogadták.

Ezzel az aspektussal teljesen átértékelődhet a történet eddigi értelme: a tüntetők valójában kommunisták, velük szemben inkább az oktató lehetett ellenzéki beállítottságú, maga az esemény így találkozhatott a vezetés és a rendőrség hallgatólagos jóváhagyásával. Habár a nem központilag szervezett demonstrációk a konszolidált, uralomváltáson túljutott pártállamban általában nem voltak kívánatosak, de a hatalom céljai érdekében, korlátozott érvénnyel akár megengedetté is válhattak. Nem tudjuk, hogy eleve meg volt-e tervezve a tüntetés, vagy 
a folyamat spontán alakult ki és formálódott, de ez a tény figyelmeztet minket arra, hogy a diáktüntetés vs. hatalom képlet közelebbről megvizsgálva akár az ellentétes oldalak átrendeződését is jelentheti. A másik lehetőség, hogy a hallgatók tudták, milyen érveket kell felhozniuk annak érdekében, hogy a céljukat elérjék - ekkor viszont a domináns ideológiát adaptáló logikáról van szó. Jugoszláviában a partizán múlt és örökség olyan legitimáló erővel bírt, aminek a megsértése súlyosabb vétség volt, mint a szakmai vagy tanulmányi kifogások, egyéb politikai érvek. A kétféle irányból érkező diskurzus (hithű kommunisták sérelmei és a rendszer ideológiáját kihasználó hallgatók) akár egyszerre is hathatott, egymást erösítve a közös cél érdekében, koalíciót létrehozva Kušević ellen.

A professzor szerb származása és a szerb felsőbbrendűség hangoztatása már csak olaj volt a tüzre, ami Zágrábban biztosan érzékenyebben érintett mindenkit, mint mondjuk a Belgrádi Egyetemen. Az egyetemi szenátus így holtpontra jutott, eltávolítani nem merték, félve az így létrejövő precedenstől (két másik oktató ellen is elkezdtek már szervezkedni a hallgatók), de büntetlenül nem is hagyhatták a pártot és a partizánokat érintő kommentárjait. Ekkor már lehetségesnek tünt az eltávolítás, áthelyezés egy másik egyetemre, vagy az ügy rábízása egy külső bíróságra - ez utóbbi a döntéshozás és a felelősség átruházását jelentette volna. Amíg nem dőlt el a dolog, addig Kušević óráit a tanársegédei tartották meg, vagyis a diákok győztek, 1953-ben pedig nyugdíjba vonult az akkor ötvenhét éves professzor.

Branko Bošnjaković horvát származású professzor új megvilágításba helyezi a történéseket tanulmányában (Bošnjaković 2011, 80-81): 1950 tavaszán a Horvát Kommunista Párt Központi Bizottsága határozatot hozott az oktatásról, ami nem valósult meg, a Naprijed (a párt hivatalos lapja) szerint ezután is hiány volt a marxista ideológiát tudományterületükön tudatosan alkalmazó oktatókból; a korábban elküldött professzorok visszatérése pedig csak rontott a helyzeten, amin a keményvonalas kommunisták változtatni akartak. Különösen a Müszaki Főiskolát/Tanszéket érte sok kritika (ahol Kušević dolgozott), itt sok „rossz” előadó dolgozott, különösen a helyi pártszervet támadták, mivel meg akartak akadályozni egy olyan professzori kinevezést, amit a kommunista diákszervezet viszont támogatott. Ez a párton belüli ellentét a „liberálisabb” pártszerv és a „balosabb” diákszövetség között vezetett aztán a Zágrábi Egyetemet megtisztító kampányhoz, aminek nyitánya volt a Kušević-ügy, a bojkottal és az ezt követő „spontán” demonstrációkkal, amiknek háttere máig nem ismert. Ezt követően fegyelmi eljárás következett, 1952 júniusában kikényszerítették a nyugdíjazást, ami 1953-ban lépett életbe (1953 után is vezetö pozícióban maradt azonban Kušević, építésügyi-statisztikai osztályvezetőként). Még négy professzort távolítottak el hasonló eljárással ugyaninnen. Ebben a kontextusban egyértelműen 
a diákok oldalán állt a hatalom, amely tipikus manipulációként a beavatkozását titokban akarta tartani, azt a benyomást keltve, mintha a hallgatók tömegei kényszerítették volna ki a professzor eltávolítását.

Az esetről egy CIA-összefoglaló is beszámolt (Summary of the Yugoslav Press 1951), ami további részleteket szolgáltat a tüntetés hátteréhez. A zágrábi Vjesnik 1951. november 5-i híre alapján készült, Slovenski Poročevalec című szlovén újságban megjelent tudósítást használta fel az amerikai hírszerzés itt, tehát kétszeres áttételről van szó, szemben McVicker konzul valószínűleg közelebbi forrásokból szerzett ismereteivel. A cikk szerint október 15-étől megtagadták a diákok Kušević óráinak látogatását (feltételezhetően a statisztikavizsga után), fő kifogásuk az volt, hogy a professzor mindenröl beszélt, csak statisztikáról nem, így nem tudtak felkészülni a tárgyból (más vádakat nem említ a riport). Ezután jött a dékán döntése, hogy november 2-áig bezárják a tanszéket, a hallgatók október 31-i tanácskozásukon ez ellen tiltakozva vonultak fel - ez nagyon fontos különbség az előző leírással szemben, hiszen itt már nem egy spontán akcióról van szó, hanem tudatos cselekvésről. A rektor vizsgálóbizottságot küldött ki az ügy tisztázására, és a Müszaki Főiskolát újranyitották.

Ugyanarról az eseményről, a rendelkezésre álló források függvényében, még amerikai olvasatban is több nézőpontot tükröző beszámoló készült (igaz, a legutolsó feltehetően csak egy cikk kivonata volt, de ebben nem lehetünk biztosak, mert a CIA hivatalnokai nem mindig különítették el a saját kommentárjaikat hasonló összefoglalóknál). Az oktató-hallgató ellentét hagyományos pedagógiai okai mellett feltünt a politikai szál, ma már nem eldönthető módon összekeverve a hangsúlyokat, ami talán nem is olyan meglepő. A hidegháborús 1951. évben (és később) akármilyen eseményt politikai dimenzióban értékeltek a résztvevők és a kommentárok; az ismertetett bizonyítékok azonban azt valószínüsítik, hogy a politika valóban beavatkozhatott ebben az esetben, nem úgy, mint a későbbi diákmegmozdulások során. 1951. december 9-én, a Jugoszláv Kupa elődöntője után nacionalista felhangú zavargások kezdődtek Zágrábban, miután a belgrádi Crvena zvezda legyőzte a zágrábi Dinamót: a demonstrálók a Marjane, Marjane partizándal háború előtti változatát énekelték, illetve a „Horvátország még nem bukott meg!" jelszavát skandálták (Tuđen 2019). 1954-ben újabb tüntetés volt a Zágrábi Egyetemen, egy győztes horvát focimeccs miatt (ne feledjük, hogy ugyanebben az évben volt Magyarországon az első nagyobb tömegdemonstráció az elvesztett futball vb miatt!), a diákok jelszava (Le a kalappal!) a szerbhorvát nyelvben összetéveszthető volt a „Le a Kommunista Párttal!” felszólításával. Az ezt követő nacionalista tüntetésen a milícia oszlatott, sok embert letartóztatva. Szintén 1954-ben, a Belgrádi Egyetemen már zavargásokká fajult a kollégiumi díjak felemelése és a közlekedés drágulása, amit csak erőszakkal tudtak leverni (McVicker 1957, 199). 


\section{Befejezés}

Érdekes, hogy az 1951-es, 1954-es zágrábi és belgrádi egyetemi események, továbbá az 1968-as belgrádi és párizsi diáklázadások nagyon sok szempontból hasonlónak tűnnek. Párizs egyik külvárosában, Nanterre-ben szintén az oktatási körülmények miatt kezdtek el szervezkedni a hallgatók, a kollégium volt az egyik fő helyszín, és az egyetemi vezetés az épület lezárásával igyekezett kanalizálni a folyamatot, gátat szabni a további megmozdulásoknak, de ez további radikalizálódáshoz vezetett. A Belgrádi Egyetemen az 1968-as diáksztrájk azzal kezdődött, hogy egyetemistákat nem engedtek be valahová (ekkor egy föpróbára), ami a felsőoktatási intézmény elfoglalásához és radikális követelések megfogalmazásához vezetett (Juhász 2009). Bizonyos szempontból nem meglepő az események hasonlósága. A tér kontrollálása a tömeg és a hatalom szempontjából is fontos (Vörös 2016), nem csoda, hogy az egyetemi épület lezárása indította meg Franciaországban és Jugoszláviában is a további cselekvés előtt a teret, ami után mindkét esetben a Rektori Hivatalhoz vonultak a tüntető csoportok. A hallgatók ezzel átléptek egy határt, elfoglaltak egy előlük általában elzárt teret, tettüket több-kevesebb siker koronázta.

A hasonlóságok mögött azonban meg kell látni az egyedi esetek és értelmezések különbözőségét. Egy eseménysorról teljesen más véleményt alkotott kis időbeli eltéréssel a korabeli, kívülálló szemtanú, ami a birtokában lévő információk módosulásának, kiegészítésének volt köszönhető; de lehetséges, hogy közrejátszottak ebben saját előzetes feltevései a rendszert és müködését illetően. McVicker 1951-ben azt írta az USA Nemzetbiztonsági Tanácsának, hogy a viszonylag független Jugoszlávia akkor tartható fenn, ha az Egyesült Államok a jelenlegi, Tito-féle rezsimet támogatja. Ez a felfogás az ötvenes évektől egészen a hetvenes évekig dominálta az amerikai külügyi gondolkodást Jugoszlávia irányában (Jakovina 2008, 156), ami biztosan megengedőbbé tette az itt történt események értelmezését.

A szerepek és cselekvések egymást akár diametrálisan kizáró interpretációi ezért egy időben, akár egyszerre is érvényesek lehettek, attól függően, hogy milyen nézőpontból tekintünk rájuk, gondoljunk a tüntetés vagy Kušević megítélésére ebben az esetben. A legfőbb következtetés az, hogy mindig több lehetőséget vegyünk számításba a történeti múlt feltárásában, ami közelebb áll a valóság komplexitásához, mint a leegyszerüsítő magyarázatok. A kommunista rendszerek müködésmódját általában az irányítók, párt-jegyzőkönyvek alapján vizsgálják, de keveset tudunk az alávetettek viselkedésmódjairól, gondolatairól, ehhez a hiányzó, még nem teljesen feltárt vizsgálati területhez kínál rövid és részleges adalékokat ez az írás. Nagyon érdekes kutatói kérdésként merül fel a spontán és megszervezett demonstrációk kérdése, az a fajta rejtett hatalmi beavatkozás, 
ami propagandisztikus eszközként használta fel a tömegeket, a felszínen teljesen más értelmet adva az eseményeknek. Kušević esetében lehetséges, hogy éppen a hatalom érte el a célját, de ezt úgy állította be, mintha ennek az ellenkezője lenne igaz. Tanulmányomban csak az amerikai forrásokat használtam, amiket természetesen ki lehet egészíteni a horvát, szerb dokumentumokkal, szakirodalommal, az akkori résztvevők esetleges visszaemlékezéseivel, teljessé és még bonyolultabbá téve a kontextust.

\section{Irodalom}

\section{Források}

Foreign Service List, April 1, 1951. 1951. Washington: Department of State.

McVicker, Charles P. 1957. Titoism: Pattern for International Communism. New York-London: St. Martin's Press-Macmillan \& Co. Ltd.

More about Professor Kušević. 1951. Despatch No. 118, Nov. 29. 1951. Central File: Decimal File 868.43, Internal Economic, Industrial and Social Affairs, Yugoslavia, Education. January 4, 1950 - July 21, 1954. MS Socialism and National Unity in Yugoslavia, 1945-63: Records of the U. S. State Department Classified Files: Records of the Department of State relating to Internal Affairs: Yugoslavia 1950-54. National Archives (United States). Archives Unbound. http://tinyurl.galegroup.com/tinyurl/75YLv32 (2018. szept. 19.)

Student Demonstration at Zagreb University on Oct. 31, 1951. 1951. Despatch No. 100, Nov. 6. 1951. Central File: Decimal File 868.43, Internal Economic, Industrial and Social Affairs, Yugoslavia, Education. January 4, 1950 - July 21, 1954. MS Socialism and National Unity in Yugoslavia, 1945-63: Records of the U. S. State Department Classified Files: Records of the Department of State relating to Internal Affairs: Yugoslavia 1950-54. National Archives (United States). Archives Unbound. http://tinyurl.galegroup.com/ tinyurl/75YLv32 (2018. szept. 19.)

Summary of the Yugoslav Press 1951. Nov. 8. 1951. Joint Translation Service. CIA-RDP8300415R010400040016-4. https://www.cia.gov/library/readingroom/docs/CIA-RDP8300415R010400040016-4.pdf (2020. márc. 8.)

\section{Szakirodalom}

Apor Péter. 2014. Az elképzelt köztársaság: A magyarországi Tanácsköztársaság utóélete, 1945-1989. Budapest: MTA BTK TTI.

Békés Csaba. 2019. Enyhülés és emancipáció. Budapest: Osiris-MTA TK.

Bošnjaković, Branko. 2011. Science and Higher Education in Croatia in the First Half of the $20^{\text {th }}$ Century: Between Academic Freedom, Authoritarian State and Migration. In Scholars in Exile and Dictatorships of the $20^{\text {th }}$ Century, eds. Stella, Marco; Štrbáňová, Soňa \& Kostlán, Antonín. 30-89. Prague: Centre for the History of Sciences and Humanities of the Institute for Contemporary History of the ASCR.

Farkas Gyöngyi. 2016. Lázadó falvak. Budapest: Korall. 
Jakovina, Tvrtko. 2008. Where Has War for Hearts and Souls Gone? The United States of America and Liberals in Yugoslavia in 1960' and Early 1970'. In 125 Years of Diplomatic Relations between the USA and Serbia, ed. Trgovčević, Ljubinka. 149-164. Belgrade: Faculty of Political Sciences University of Belgrade.

Johnson, Mark S. 1996. From delinquency to counterrevolution. Subcultures of Soviet youth and the emergence of Stalinist pedagogy in the 1930s. Paedagogica Historica 32(sup1): 283-303.

Juhász József. 2009. 1968 Jugoszláviában és Csehszlovákiában. In 1968: Kelet-Európa és a világ, szerk. Bartha Eszter-Krausz Tamás. 79-86. Budapest: L'Harmattan-ELTE BTK Kelet-Európa Története Tanszék.

Konta, Carla. 2016. Waging Public Diplomacy: The United States and the Yugoslav Experiment (1950-1972). Dissertation. Trieste: Università degli studi di Trieste.

Kotkin, Stephen. 1997. Magnetic Mountain: Stalinism as a Civilisation. Berkeley: University of California Press.

Lynne, Violet. 1996. Peasant Rebels Under Stalin. Oxford: Oxford University Press.

Milošević, Nemanja. 2007. Yugoslavia, USA and NATO in the 1950s. Western Balkans Security Observer 5: 64-80.

Nagy Ágnes. 2014. Harc a lakáshivatalban. Budapest: Korall.

Somogyvári Lajos. 2019. A szovjet ideológiai befolyást ellensúlyozó amerikai kulturális és oktatási programok (1948-1958). In Tudományágak integráló és integrált szerepe, szerk. Tóth József. Budapest: Akadémiai Kiadó, elektronikus kiadvány. https://mersz. hu/hivatkozas/m623tieisz_31_p1\#m623tieisz_31_p1 (2020. márc. 14.)

Tuđen, Branko. 2019. Prve demonstracije u Zagrebu bile su 1951. nakon dvoboja sa Zvezdom. Večernji list. https://www.vecernji.hr/sport/prve-demonstracije-u-zagrebu-bile-su-1951nakon-dvoboja-s-crvenom-zvezdom-1342652 (2020. máj. 20.)

Vörös Boldizsár. 2016. Terek, tömegek, filmek. Rendezvények magyar híradókban 1915-ben és 1919-ben. In Propaganda - politika, hétköznapi és magas kultúra, müvészet és média a Nagy Háborúban, szerk. Bertényi Iván, ifj.-Boka László-Katona Anikó. 303-312. Budapest: OSZK.

\section{Lajoš ŠOMOĐVARI}

\section{DEMONSTRACIJE U AMERIČKOM TUMAČENJU: UNIVERZITET U ZAGREBU, 1951}

Digitalizacijom izveštaja američkog Stejt Departmenta, kompanija Gejl objavila je niz izvora u obliku tematskih zbirki koje pružaju važne dopune istoriji Centralne i Istočne Evrope posle 1945. Hladni rat nije značio samo vojnopolitičke konfrontacije i takmičenje dva suprotstavljena bloka, već i kulturno takmičenje u kojem je bilo od ključnog značaja da obe supersile dobiju što više informacija o institucijama i slabim tačkama suprotne strane. $\mathrm{Na}$ američkoj strani se o ovome može mnogo saznati jer je obilje dokumenata koji se mogu pretraživati putem interneta (što se ne može reći za slične aktivnosti na sovjetskoj strani) - 
ovaj rad govori o prvom velikom studentskom pokretu novog jugoslovenskog režima posle Drugog svetskog rata, koji se dogodio na Univerzitetu u Zagrebu 31. oktobra 1951. Ovaj rad predstavlja američko tumačenje svega toga na osnovu dva konzularna izveštaja i jednog izveštaja CIA-e, koji su posebno važni jer je ostalo malo drugih, nesocijalističkih izvora o sličnim događajima.

Ključne reči: studentske demonstracije, Stejt Department, CIA, hladni rat, Univerzitet u Zagrebu

\section{Lajos SOMOGYVÁRI}

\section{DEMONSTRATIONS IN AMERICAN INTERPRETATION: UNIVERSITY OF ZAGREB, 1951}

Digitizing U.S. State Department reports, the Gale Company has published a number of sources in the form of thematic collections that provide important additions to the history of Central-Eastern Europe after 1945. The Cold War meant not only a military-political confrontation and competition between the two blocs, but also a cultural competition in which it was vital that the two superpowers obtain as much information as possible about each other's institutions and vulnerabilities. On the American side, we can learn a lot about this, as many documents can be searched online (the same cannot be said of the similar activities on the Soviet side) - this paper is about the first major student movement of the new post-World War II Yugoslav regime, which took place at the University of Zagreb on October 31, 1951. I present the American interpretation of this event on the basis of two consular reports and one CIA report, which are of particular importance as few outside, non-socialist sources of similar events have survived.

Keywords: student demonstration, US State Department, CIA, Cold War, University of Zagreb 